\title{
The Transliteration Principle: Is this the Best Procedure in African Language Lexicography and Terminology?
}

Motlokwe Clifford Mphahlele, Sesotho sa Leboa National Lexicography

Unit, University of the North, Polokwane, Republic of South Africa

(motlokwem@unorth.ac.za)

\begin{abstract}
The creation of target language equivalents in bilingual dictionaries have always been a challenge to both lexicographers and terminologists. Lexicographers, terminologists, subject specialists and linguists face a challenging task of supplying term equivalents for foreign international languages. The lack of a sufficient technical vocabulary in the African languages poses challenges to lexicographers and terminologists when supplying technical equivalents. They often regard transliteration as the quickest lexicographical and terminological procedure without taking the practical demands of users into account. This impedes the optimal retrieval of semantic information by the target users of dictionaries. This article discusses possible reasons why transliteration should not be regarded as the first but the last resort in lexicography and terminology. It proposes different lexicographical and terminological procedures lexicographers and terminologists can use to supply accurate and appropriate translation equivalents without making excessive use of transliteration. In this way a scientific language will develop which could assist users to communicate successfully in the mother tongue.
\end{abstract}

Keywords: TERMS, TERM EQUIVALENTS, TERMINOLOGISTS, SUBJECT SPECIALISTS, LINGUISTS, INTERNATIONAL LANGUAGES, INTERNATIONAL SCIENTIFIC LANGUAGES, UNDERDEVELOPED LANGUAGES, TRANSLITERATION, TERMINOLOGICAL PRINCIPLE, TRANSLATION EQUIVALENTS, SEMANTIC INFORMATION, BORROWING, TARGET LANGUAGE.

Opsomming: Die transliterasiebeginsel: Is dit die beste werkwyse in die leksikografie en terminologie van die Afrikatale? Die skep van doeltaalekwivalente in tweetalige woordeboeke was altyd 'n uitdaging vir sowel leksikograwe as terminoloë. Leksikograwe, terminoloë, vakspesialiste en taalkundiges staan voor 'n uitdagende taak om termekwivalente vir vreemde internasionale tale te verskaf. Die gebrek aan 'n voldoende tegniese woordeskat in die Afrikatale stel probleme aan leksikograwe en terminoloë by die voorsiening van tegniese ekwivalente. Hulle beskou transliterasie dikwels as die vinnigste leksikografiese en terminologiese werkwyse sonder om die praktiese eise van die gebruikers in ag te neem. Dit belemmer die optimale herwinning van semantiese inligting by die teikengebruikers van woordeboeke. Hierdie artikel bespreek moontlike redes waarom transliterasie nie as die eerste nie, maar as die laaste uitweg in leksikografie en terminologie beskou moet word. Dit stel verskillende leksikografiese en termi-

Lexikos 14 (AFRILEX-reeks/series 14: 2004): 339-348 
nologiese werkwyses voor wat leksikograwe en terminoloë kan aanwend om juiste en gepaste vertaalekwivalente te voorsien sonder om buitensporige gebruik van transliterasie te maak. Op hierdie manier sal 'n wetenskaplike taal ontwikkel wat gebruikers kan help om suksesvol in die moedertaal te kommunikeer.

Sleutelwoorde: TERME, TERMEKWIVALENTE, TERMINOLOË, VAKSPESIALISTE, TAALKUNDIGES, INTERNASIONALE TALE, INTERNASIONALE WETENSKAPLIKE TALE, ONDERONTWIKKELDE TALE, TRANSLITERASIE, TERMINOLOGIESE BEGINSEL, VERTAALEKWIVALENTE, SEMANTIESE INLIGTING, ONTLENING, DOELTAAL

\section{Introduction}

The creation of target language term equivalents for new foreign concepts is not as easy as it may seem. This creation of terms should not be done in a haphazard way but systematically according to the general terminological principles. Lexicographers, terminologists, subject specialists and linguists face a challenging if not difficult task of supplying term equivalents for foreign international languages. Underdeveloped languages such as African languages largely lack a technical vocabulary and this necessitates the speedy development of a technical terminology. As English enjoys worldwide recognition as a language of international scientific and technical communication and also due to the fact that many scientific texts are published in English, it is often encounterd as source language in terminology. Therefore, African language terminologists, lexicographers, subject specialists and linguists have to create accurate new term equivalents in their mother tongue for the multitude of terms in English. Trying to cope with this challenge, they apply transliteration as a lexicographical and terminological principle. They often regard transliteration as the quickest lexicographical and terminological procedure without taking into consideration the practical demands of the target users. This therefore impedes an optimal retrieval of semantic information in the target language. The prescriptive nature of the terminological work should not tempt terminologists and their collaborators to supply term equivalents not having any meaning and conceptual equivalence with the source language terms.

The purpose of this article is to propose possible ways to prevent the excessive use of transliteration. Transliteration should not be regarded as the first but the last resort in terminology creation. Different terminological procedures terminologists can use to supply accurate and appropriate translation equivalents that could assist users to communicate successfully in scientific language in their mother tongues will be discussed.

This article aims to show lexicographers, terminologists, subject specialists and linguists how appropriate and accurate term equivalents could carry the same meaning and concept of the original scientific term without the excessive use of transliteration. Duplication of the stem of the source language term (transliteration) cannot, in many cases, assist target users to retrieve semantic 
information unless such a source language term has already been established in the target language. This is why transliteration often fails target users because the foreign concept is not easily transmitted into the target language.

\section{Preventing the excessive use of transliteration}

Transliteration can be defined as the use of a foreign language stem to coin a target language equivalent. In most countries, English has emerged as a lingua franca and also as a language of choice. This has therefore made African language speakers to adopt foreign languages by means of borrowing, neologising, transliterating, etc. The remainder of this article will focus on transliteration as an optional terminological procedure.

As target language speakers, African language lexicographers, terminologists, subject specialists and linguists are tempted to supply a transliteration in a case where there is lack of a target language term equivalent. In most cases, this terminological procedure has not succeeded in assisting terminology users to retrieve the required information. The lack of target language term equivalents entails zero equivalence, i.e. lack of equivalents in the target language. In cases where zero equivalence occurs, many languages have coined and are still coining target language equivalents from foreign words. "Zero equivalence entails a lexical gap," says Gouws (1999: 26). "That is, the lexical item that is supposed to be supplied as a translation equivalent is not present. The absence of a translation equivalent usually indicates the existence of a lexical gap in the target language." In terminology, it would be appropriate to speak of the existence of a terminological or conceptual gap if a ready term equivalent is absent in the target language. According to Al-Kasimi (1977), a major problem confronting the bilingual lexicographer is that the required equivalents in the target language cannot always be found. This is also the case with terminologists, subject specialists and linguists: they cannot always find ready term equivalents in the target language. Al-Kasimi differentiates between two types of vocabulary that contribute to this problem, i.e. culture-bound words and scientific and technological terminology. The fact that a lexicographer cannot find the required equivalents does not mean that borrowing must be utilised (cf. Mphahlele 2001: 27). In cases where zero equivalence occurs, the lexicographer should bear in mind that direct borrowing from the source language cannot serve any semantic purpose. That is, a borrowed word which has not been established in general language use cannot assist the user to communicate successfully (Mphahlele 2001: 27). This is also the case in terminology. When the stems of the source language terms are retained as target language equivalents (as in transliteration), there is no way in which a user could be assisted to comprehend the source language term, unless such a term has been established in the target language.

With regard to transliteration, Roets (2001: 9) observes: "A large number of equivalents are formed through transliteration, particularly in subjects such as 
Economics, Medicine and Physics. However, this does not mean that transliteration is the best solution. Although English is the language of transit in South Africa for most scientific and technical subjects, the English language has a limited use for young African learners." According to Roets, transliteration should not be regarded as the first solution when supplying target language equivalents. This is true, because most African learners do not understand English words. In this case, if transliteration is excessively used in terminology there is no way in which learners could understand the stems of the English words retained as possible term equivalents. In other words, new target language term equivalents would remain foreign even when transliterated. This means that foreign concepts are not understood in the target language. Transliteration could only serve a semantic purpose if the source language terms are known or well established in the target language. If not, the transliterated source language forms could only remain foreign term equivalents without any meaning or concept attached to them in the target language. This procedure therefore fails the terminology user. The Northern Sotho examples in Table 1 illustrate this point:

Table 1

\begin{tabular}{|ll|}
\hline formula & - fomula \\
fraction & - frakšin \\
equilibrium & - ekhwilipramo \\
pictogramo & - pictokramo \\
\hline
\end{tabular}

If the new Northern Sotho Mathematics terminology is designed in this way, the target users would not understand the source language terms. In the above examples, the English mathematics term formula is supplied with a Northern Sotho transliteration fomula. The question here is whether a native speaker of Northern Sotho has ever heard of an English mathematical term formula. If not, then this transliterated Northern Sotho term cannot assist users in understanding the meaning and contextual use of the source language term formula. This is also the case with the other English mathematics terms fraction, equilibrium and pictogram. If users have not heard of these terms before, transliteration could therefore not serve any semantic purpose. That is, in most cases transliteration does not assist users to retrieve the required information regarding the source language terms. Transliteration could only be opted for if speakers of the target language know or have heard of the source language terms. If this is not the case, transliteration would therefore just be a mere duplication of the source language terms. If speakers of the target language do not know the foreign concept or referent, terminologists should make sure that the concept is transmitted into the target language by appropriate terminological procedures. With regard to these, Roets (2001: 10) gives general guidelines regarding the acceptance of terminology. According to her, the new terminology is acceptable if it has concept correspondence, adheres to orthography, is appropriate, i.e. keeps to the register of the main corpus of the dictionary, is not 
in any way taboo or offensive to any gender or culture group, shows conformity with or similarity to other entries, has aptness and easy identification with the specific subject field, etc. In other words, term equivalents should have correspondence with the original concept, and display linguistic correctness and accuracy by adhering to the orthography. With transliteration it cannot be claimed that the term equivalents have concept correspondence. In most cases, new terms are incorporated into the orthography of a language after being considered as established borrowings in that language. This means that there is no way in which the newly transliterated equivalents can be claimed to adhere to the orthography of a language, because they have not been used in written language before. Although terminologists, subject specialists and linguists are permitted to have a prescriptive approach when supplying term equivalents, this does not necessarily mean that the needs of the target users should be lost sight of. In other words, some general guidelines regarding terminology should be taken into consideration so that appropriate and accurate term equivalents could be supplied.

Given that transliteration does not adhere to most of the general guidelines regarding terminology, it could not be regarded as a balanced terminological procedure. With regard to this Roets (2001: 10) says, "Do not grasp transliteration as a first, but a last resort - if all else fails. No matter if an equivalent may sound and appear like a brief explanation of a term." She believes it is better if terminologists and subject specialists give a brief meaning definition of the source language term as an equivalent. A brief meaning definition of the source language term could assist users to retrieve the required information because a meaning definition carries a concept in itself. This would be far better than the mere listing of a transliteration as term equivalent.

If transliteration is adopted as the first terminological procedure, the technical language of the developing African languages cannot evolve. Excessive use of transliteration may result in heavy borrowing because all speakers of a target language would use the new transliterated terminology. The technical terminology for African languages should be developed so that speakers of these developing languages could use their own terminology for an international technical source language when communicating. The new terminology should coincide with corresponding concepts so that speakers of the developing language could benefit from using international technical language in their mother tongue. In terminology, the source language terms are standardised by means of definitions for each term. Exact communication is possible if there is a one-to-one relation between term and concept. These definitions assist terminologists and their collaborators to supply appropriate term equivalents. With transliteration, definitions supplied for standardisation are sometimes ignored. According to Cluver (1978: 91), a technical dictionary is a bi- or multilingual dictionary which includes the standardised terms of a particular subject field, with or without a full definition for each term. When supplying term equivalents, terminologists and their collaborators should read and understand the 
supplied definitions so that their term equivalents could be accurate. Alberts (1990) also describes a multilingual technical dictionary as including an alphabetical list of terms in the source language and equivalents in several languages. According to her, this alphabetical list of terms is standardised for creating better term equivalents.

\section{Towards new independent term equivalents}

Roets (2001: 1) states that, for a language to develop, the daily growth of human knowledge in the science and technology of developed countries needs to be shared with developing countries and, to this end, expressed in mother tongue terminology. According to her, this is also important as the status of a language depends on its possession of a technical vocabulary. The technical vocabulary of a particular language develops when technical terms are created in that particular language. New term equivalents in a target language would enable users to learn about science and technology in their mother tongue. If a language has enough technical vocabulary, its users would be able to communicate by means of technical language. According to Roets (2001: 1), the South African terminographer's mission is to stay informed of emerging international developments in all fields of learning and to translate these from a language of transit into mother tongue equivalents for expressing the vast number of new concepts that have to be mastered for technical communication. If international scientific terms are translated into African languages, speakers of African languages would be able to learn and communicate in scientific languages.

Avoiding the excessive use of transliteration, lexicographers, terminologists, subject specialists and linguists should always strive for new independent term equivalents having a one-to-one relation with the source language terms. The new term equivalents should adhere to the orthography of the target language and also have concept correspondence with the source language terms (Roets 2001: 10). These new terms should be the result of terminological, scientific and linguistic decisions taken by collaborators.

The Northern Sotho examples in Table 2 can be considered as illustration:

Table 2

\begin{tabular}{|ll|}
\hline formula & - mokgwataetšo \\
fraction & - palopalwana \\
equilibrium & - mokgwatekatekano \\
pictogram & - tshwantšhotšhupakgopolo \\
\hline
\end{tabular}

These suggested term equivalents display a balanced terminological procedure. When looking for term equivalents, the terminology user would be able to deduce the meaning of the source language terms because there is a one-to-one meaning relation between the source language forms and the target language equivalents. In this case the terminology user would achieve communicative 
equivalence. Because of their self-explanatory nature the supplied term equivalents have transparent meanings and are therefore easily comprehensible. As can be seen, the supplied term equivalents are independent from the original English terms, i.e. the stems of the source language terms have not been retained or borrowed when creating term equivalents. This is what terminologists, subject specialists and linguists should actually do when creating term equivalents. Transliteration should only be opted for if all measures to supply term equivalents have failed.

Rather than adopting the transliteration principle as a lexicographical and terminological procedure, lexicographers, terminologists and their collaborators should try to create new term equivalents having a meaning relation with the source language terms. This would help developing the technical vocabulary of a language.

The examples from Alberts (2001: 2) in Table 3 display a better terminological procedure:

Table 3

\begin{tabular}{|c|c|c|}
\hline English & Afrikaans & Northern Sotho \\
\hline $\begin{array}{l}\text { common law } \\
\text { common (general) law } \\
\text { common law } \\
\text { common law marriage } \\
\text { common law wife }\end{array}$ & $\begin{array}{l}\text { gemene reg } \\
\text { gemene reg } \\
\text { gemene reg } \\
\text { gemeenregtelike huwelik } \\
\text { gemeenregtelike vrou }\end{array}$ & $\begin{array}{l}\text { molao wo o sego wa ngwalwa } \\
\text { molao wa bohle nageng } \\
\text { molao wa setlwaedi } \\
\text { lenyalo la molaotlwaedi } \\
\text { mosadi wa semolao }\end{array}$ \\
\hline
\end{tabular}

In legal terminology, the above presentation of term equivalents could enable users of Afrikaans and Northern Sotho to retrieve the required information. In this case, interpreters and translators are enabled to achieve communicative success. Because of its multilingual nature, the above terminology would serve the dual purpose of assisting Afrikaans and Northern Sotho interpreters and translators.

According to Sager (1990: 57), special languages strive to systematise principles of designation and to name concepts according to pre-specified rules or general terminological principles. Using general terminological principles, terminologists, subject specialists and linguists could name concepts in an accurate and systematic way. Sager (1984: 317) says that "terminology is strongly involved in the creation of new designations and is therefore interested in a theory of active, productive term-formation". In creating new terms, terminologists and their collaborators should also take the level (referential skills) of target users into consideration so that the new terminology created could be suitable for and comprehensible to them. If research regarding the target users of terminology is not done, it is therefore likely that term equivalents may be too difficult for the target users. The excerption of terms together with their term equivalents should be done in accordance with the level of target users so that the created terminology could assist them in retrieving the required information. The Terminology Division of the National Language Service (NLS) have 
designed different terminology worklists for terminologists and their collaborators so that term equivalents could be suitable for and comprehensible to different levels of learners.

Table 4 shows page 1 of the SCHOOL PROJECT: MATHEMATICS GRADE 1-7 Worklist 1 (National Language Service: 1 September 2001):

\section{Table 4}

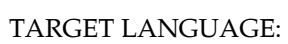

Terms shown in the above table were excerpted by terminologists who provided them with definitions so that accuracy and concept correspondence could be easy in the target language. These definitions enable terminologists, subject specialists and linguists to supply appropriate term equivalents. Supplying transliteration equivalents for the above terminology would undermine the work done by terminologists. The supplied example sentences (in the source 
language) are meant to assist collaborators of terminologists to give term equivalents having concept correspondence with the source language terms.

\section{Conclusions}

As becomes clear from the previous discussion, supplying term equivalents for international technical languages is not an easy task for terminologists. In their terminological work, lexicographers, terminologists, subject specialists and linguists should try to adhere to the general terminological principles available. They should try to move away from a dependent approach in the formation of term equivalents and try to be productive and creative. For supplying term equivalents the following conclusions could be useful to terminologists:

- Transliteration should not be regarded as the first but the last solution after all measures for supplying term equivalents have failed.

- The new term equivalents should have concept correspondence, adhere to the orthography of the target language (i.e. display linguistic correctness), show aptness and be easily identifiable with the subject field.

- Transliteration does not necessarily assist in the development of technical language, i.e. if transliteration is used excessively, the technical vocabulary of the target language is not allowed to develop.

- Because the stems of source language terms are retained in the target language, transliteration may result in heavy borrowing.

- If the referent or concept is unknown to speakers of the target language, transliteration could not serve any semantic purpose because even the transliterated term equivalents may still be unknown to the terminology user. In other words, with transliteration a referent or concept may still be foreign to speakers of the target language. In this case, the user is not assisted in retrieving the required information.

- Transliteration could only be opted for if speakers of the target language know the referent or concept. In this case, the retained stem may display concept correspondence with the original source language term.

- Lexicographers, terminologists, subject specialists and linguists should always strive for term equivalents that display accuracy and dependence of the orthography of the source language.

- For a better and balanced terminological practice, definitions supplied for the source language terms should be considered because they serve a standardisation purpose. That is, the supplied definitions assist terminologists, subject specialists and linguists to supply appropriate term equivalents having a one-to-one relation with the source language terms. 


\section{Bibliography}

Alberts, M. 1990. 'n Bepaling van Afrikaanse vakleksikografiese behoeftes. D.Litt. et Phil. Thesis. Pretoria: UNISA.

Alberts, M. 2001. Terminology: Principles and Practice. Unpublished Document. Pretoria: DACST.

Al-Kasimi, A.M. 1977. Linguistics and Bilingual Dictionaries. Leiden: E.J. Brill

Cluver, A.D. de V. 1978. Die Terminologie. Van Schalkwyk, C. et al. (Comp.). 1978. Diploma in Vertaling: 67-131. Pretoria: UNISA.

Gouws, R.H. 1999. Equivalent Relations in Translation Dictionaries. M.Phil. Study Guide. Stellenbosch: University of Stellenbosch

Mathematics Terminology Worklist. 2001. School Project: Mathematics Grade 1-7. Pretoria: DACST.

Mphahlele, M.C. 2001. A Model to Achieve Communicative Equivalence in Translation Dictionaries. Unpublished M.Phil. Thesis. Stellenbosch: University of Stellenbosch.

Roets, S. 2001. Preliminary Stages of a Terminographic Project. Unpublished Article. Pretoria: Department of Arts and Culture.

Sager, J.C. 1984. Terminology and the Technical Dictionary. Hartmann, R.R.K (Ed.). 1984. LEXeter '83 Proceedings. Papers from the International Conference on Lexicography at Exeter, 9-12 September 1983: 315-326. Lexicographica. Series Maior 1. Tübingen: Max Niemeyer.

Sager, J.C. 1990. A Practical Course in Terminology Processing. Amsterdam: John Benjamins. 